\title{
Additions and Elaborations
}

The notion that Jane Austen must be improved on also finds expression in explanations and new additions. This is the chosen method and most distinguishing feature of the oldest translation in our Norwegian material, and also frequently exploited in those from the mid-twentieth century.

It may evidently be motivated by a wish to clarify the text and inform the readers. In other cases, it seems a sign of uncertainty about linguistic choices in the target language, and about the meaning of words in the source language. ${ }^{1}$ The first bears witness of a well-informed translator, the second a weaker one.

\section{Two for the Price of One in 1871}

From the very first chapter, the 1871 translator of Persuasion - in other respects so capable - expands the text of the novel, not by inventing or adding any new content, but by choosing translations that simply contain more words than the original text. ${ }^{2}$ As a result, there are passages throughout the novel that are several lines longer in translation, even in comparable formats. Counting the words is a more reliable method of comparison, and in the most extreme cases, the text may be expanded from seven to twenty-five words: "She spoke, and seemed only to offend" (34) becomes "Thus Anne, then, one day spoke her mind, but had, as it appeared, no other reward for this than that Elizabeth became angry and resentful". ${ }^{3}$

The translator seems to enjoy making the most of such expressions as "in a sort of desolate tranquillity" about Anne's mood as she was leaving her home early in the book (36). This becomes two separate phrases: "In a depressed state of mind, but quiet and resigned as always" before the original sentence,

1 American pioneer theoretician Eugene Nida, an authority on Bible translation, set up categories of additions, sorting them into nine main types (see Routledge Encyclopedia of Translation Studies, 81).

2 There is one passage, though, where the 1871 translator seems to be inventing rather than translating, in five added lines about Mr Hayter ploughing up old parkland in Chapter 10. It is one of the rare instances where the translator seems not to understand the original (Austen, Familien Elliot, 30 December 1871.).

3 "Saaledes tog da Anne en Dag Bladet fra Munden, men havde, som det lod, intet Andet igjen derfor, end at Elizabeth blev vred og fortørnet" (Austen, Familien Elliot, 23 December 1871).

(C) MARIE NEDREGOTTEN SøRBø, 2018 | DOI 10.1163/9789004337176_005

This is an open access chapter distributed under the terms of the prevailing C.C-BY-NC License. 
and then after it: "An indescribably depressing feeling of emptiness and loneliness had possessed her". ${ }^{4}$ Judging from such readiness to embroider on the original story, it would be no surprise to find that the unknown translator is also a writer. There is an evident enjoyment in verbalization and descriptions.

One particularly striking feature is the tendency to substitute two words or concepts for one - perhaps the translator had a preference for parallelisms. A shortlist includes:

$\begin{array}{ll}\text { Singularity } & \text { singular or unique } \\ \text { Surprised } & \text { surprised and astonished } \\ \text { Wit } & \text { wit and humour } \\ \text { Imprudence } & \text { carelessness and imprudence } \\ \text { Feelings } & \text { feelings and views } \\ \text { Ill-will } & \text { ill-will and disapproval } \\ \text { Cold meat } & \text { sandwiches and cold roast } \\ \text { Precedence } & \text { rank and birth } \\ \text { Spirits } & \text { health and humour } \\ \text { Performance } & \text { singing and playing } \\ \text { Consideration } & \text { fineness and delicacy } \\ \text { Poor (Richard) } & \text { poor precious; poor dear } \\ \text { Tired } & \text { tired or bored } \\ \text { Wise } & \text { wise and right } \\ \text { Scornfully } & \text { scorn and contempt } \\ \text { Usefulness } & \text { usefulness and joy } \\ \text { Wretchedness } & \text { grief and worry } \\ \text { Clever } & \text { wise and learned } \\ \text { Respect } & \text { esteem and goodness; esteem and respect } \\ \text { Surprise } & \text { surprise, we may perhaps say perplexity }\end{array}$

4 Additions in italics: "I tungsindig Stemning, men stille og resigneret som alltid, forlod Anne sit hjem og vandrede med til Kellynch Lodge, hvor hun skulde tilbringe den første Uge. En ubeskrivelig nedtrykkende Folelse av Tomhed og Forladthed havde bemcektiget sig hende" (ibid., 23 December 1871).

5 "Særegent eller Enestående" (Chapter 2); "overraskede og forbausede" (Chapter 3); "Vid og Lune”; "Uforsigtighed og uklogskab”; "Følelser og Anskuelser”; "Uvilje og Misbilligelse”; (all in Chapter 4); "Smørrebrød og kold Steg” (Chapter 5); "Rang og Byrd"; "Helbred og Humør"; "Sang og Spil”; "Finhed og Delikatesse”; "stakkels dyrebare/stakkels kjære" (all in Chapter 6); "trætt eller kjed af" (Chapter 8); "klogt og rigtigt"; "Haan og Foragt" (both Chapter 10); "Gavn og Glæde”; "Sorg og Kummer” (both Chapter 11); "klog og lærd” (Chapter 12); “Agtelse og Godhed" (Chapter 9); "Agtelse og Respekt" (Chapter 12,); "hans Overraskelse, vi kunne maaske sige Betuttelse" (Chapter 9) (Austen, Familien Elliot, 1871-72). 
The last one perfectly illustrates the translator's hesitations about choosing the right word. ${ }^{6}$ Evidently it was difficult deciding which Norwegian word best renders the English concept, and the translator takes the easy way out, giving two, to ensure that every nuance of meaning is covered. In none of the cases is this necessary, and it would have benefited the translation had one word or concept been decided on. The danger is that the style can sometimes become too cumbersome compared to Austen's text. When for instance four of these parallelisms occur within ten lines, the effect is wordiness rather than precision. $^{7}$

At other times, the 1871 translator elaborates in order to clarify the meaning, although again, it is hardly necessary to specify that when Elizabeth Elliot "pushed away" the book, she "replaced it in the book cabinet". ${ }^{8}$ It is more useful to have Sir Walter's reference to "his own man" replaced by "The Baronet's valet". ${ }^{9}$ There are many such "explicitations". ${ }^{10}$ To add a few words here and there amounts to a main method of translation.

The nineteenth-century translator also has more of a taste for metaphorical language than Austen does, inserting new idioms, which, however, mostly feel quite appropriate in the context.1 ${ }^{11}$ Still, some metaphors are rather trite. Austen's version - "A short period of exquisite felicity followed, and but a short one. Troubles soon arose" (26) - is replaced by "The sunshine of their happiness was, however, soon darkened by the threatening clouds of a storm". ${ }^{12}$ Austen's sparseness and precision is in such cases replaced by standard clichés, even if the original intention was perhaps their playful use.

6 Sometimes, none of the two alternatives seems to fit the bill, such as when "prudence" is rendered "calculated and prosaic" ("beregnet og prosaisk", ibid., Chapter 4).

7 There is a strong likelihood that the translator is the same as that for the 1878 translation of George Eliot's The Lifted Veil, which is also marked by numerous expansions and a fondness for two or three parallel words instead of one. Nonetheless, both translations testify to a good command of English and an excellent understanding of the story (George Eliot, Det løftede slør, Oslo: Aftenposten, 1878).

$8 \quad$ "sat den ind i Bogskapet igjen" (Austen, Familien Elliot, 20 December 1871).

9 "Baronetens Kammertjener" (ibid., 23 December 1871).

10 "The technique of making explicit in the target text information that is implicit in the source text" (Routledge Encyclopedia of Translation Studies, 80).

11 Examples of such Norwegian idioms are for instance: "Det var isandhed at koge Suppe paa en pølsepind" (15 January 1872); and "Det er saa vist som Amen i Kirken” (Chapter 21). For maritime metaphors, see page 153 below.

12 "Deres Lykkes Solskinn blev imidlertid snart formørket av truende Uveirs skyer" (ibid., 22 December 1871). 


\section{Mid-twentieth-Century Additions to Pride and Prejudice}

Unlike his anonymous nineteenth-century colleague, Alf Harbitz (1930) seems to have only an occasional and limited need to explain and interpret. He states that Lydia had lost her heart to Captain Carter, which is not said in the novel. He also explains that Lady Catherine had gone over Mr Collins' house from top to bottom, which is clearly implied, but not stated in the original. He claims that Kitty looked "desperate" at Mr Collins' reading of sermons, while in Austen she just "stared at him" (68). ${ }^{13}$

It is, however, in the 1947 translation that we again see the technique of elaboration extensively employed. Lalli Knutsen typically adds even more than she deletes. In I, 7 , for instance, four adjectives are added to a passage where there is none in Austen. Hence, "this subject" becomes "this interesting subject"; "said Mrs Bennet" becomes "said Mrs Bennet majestically"; "they would not offer to send her home" becomes "they are not tactless ${ }^{14}$ enough to offer her a lift home"; "the horses were engaged" becomes "had exceptionally good use for the horses". ${ }^{15}$ Similarly, Knutsen twice refers to "the poor Bingley" where Austen only has "Bingley". ${ }^{16}$ She expands Mrs Gardiner's "wonder" (255) to "happy wonder". ${ }^{17}$

The added words are often neither "exceptional" nor particularly "interesting", but often rather "poor" additions. The extended description of Lydia as "the deluded and inconsiderate sister" instead of simply "her sister" (307) may be appropriate, but it still seems something of a liberty to add new adjectives to an author's presumably carefully chosen phrases. ${ }^{18}$

This connects to a tendency to interpret and explicate the novel, sometimes with prosaic additions like expanding Miss Bingley's "we shall be in danger of hating each other" to "we - she and I - shall be in danger of hating each other" (30). ${ }^{19}$

Often Knutsen's amplifications are there to pave the way for the reader, as if Austen demands pedagogical clarifications. "You must understand" as

\footnotetext{
13 "fortvilet" (Austen, Elizabeth og hennes søstre, 1930, 28, 54, 55, 64).

14 Admittedly, the added adjective "tactless" here sharpens Elizabeth's irony at her mother's scheming.

15 "dette interessante tema"; "sa fru Bennet majestetisk"; "de ikke er taktløse nok til å by henne skyss hjem"; "hadde ualminnelig god bruk for hestene" (Austen, Stolthet og fordom, 1947, 31-33).

16 “den stakkars Bingley" (ibid., 38, 39).

17 "glad forbauselse" (ibid., 219).

18 "den villfarne og ubetenksomme søsteren" (ibid., 264).

19 "er det fare for at vi - hun og jeg - kommer til å hate hverandre" (ibid., 33).
} 
Wickham says to Elizabeth, in another appendage, talking about Darcy. ${ }^{20}$ Additions of this nature include: "but it went unnoticed", about Mr Bennet's silence at Mr Collins' arrival. ${ }^{21}$ "He calmed down" about Mr Collins giving up his reading. ${ }^{22}$ "Mr Collins was soon comforted" is a rather sardonic comment on his rapid switch from Jane to Elizabeth as potential marriage candidates. ${ }^{23}$ Mr Bennet's love of the country is extended with: "and the occupations he had there". ${ }^{24}$ His wife's meagre welcome of him when he returns from London is prefaced by the addition: "now she could not understand what he came home for". 25

When Mrs Bennet is overjoyed at seeing the approach of Mr Bingley towards the end of the novel (III, 11), Knutsen inserts three new phrases into one of Austen's sentences. The original is "Elizabeth, to satisfy her mother, went to the window - she looked, - she saw Mr Darcy with him, and sat down again by her sister" (333). The translated version reads: "Elizabeth went to the window and could see that it was really Mr Bingley arriving, and that he even was accompanied by Darcy. She shyly withdrew from the window and sat down beside Jane". ${ }^{26}$ Here, Austen herself is sparse as if to emphasize emotions too tense for words: she looked - she saw - she sat down. The translator is more expansive and interprets Elizabeth's undescribed emotions as shyness, perceivably an appropriate interpretation for a romantic heroine. Such modifications of the descriptions of love will be further discussed in Chapter 12 below.

\section{The Empty Modifiers}

Rarely are additions more at odds with Austen's own style than when translators supply modifiers for her sentences. Knutsen adds the unnecessary and very un-Austenlike "and so on". ${ }^{27}$ The Hauges do the same, using the even duller (and repeated) abbreviation of it: "osv. osv." ("etc., etc."). It is a pointless phrase that students are often warned against using in their essays, since it signals a mind at a loss for words or ideas. In such cases, the meticulous novelist is

\footnotetext{
$20 \quad$ "Skjønner De ikke det at..." (ibid.,75).

21 "så ble det ikke lagt merke til" (ibid., 64).

22 "falt han til ro" (ibid.,69).

23 "Herr Collins var snart trøstet" (ibid., 70).

24 "og de beskjeftigelser han der hadde" (ibid., 205).

25 "nå kunne hun ikke forstå hva han hadde hjemme å gjøre" (ibid., 256).

26 "Elizabeth gikk bort til vinduet og fikk se at det virkelig var Bingley som kom, og at han til og med hadde følge med Darcy. Hun dro seg sky tilbake fra vinduet og satte seg ved siden av Jane" (ibid., 287).

"og så videre" (ibid., 218).
} 
burdened with immature or helpless language. It seems particularly ill fitted to Darcy's first proposal: he talked of his feelings, and so on and so forth. ${ }^{28}$ They also let Darcy use another such abbreviation in his letter, making him less of a stylist than he is. ${ }^{29}$ Even the otherwise competent 1871 translator sometimes adds abbreviations like "etc." and "e.g." 30

Although Austen may on occasion use an "\&c." herself, it is rare. Apart from the "Yours \&c." that ends the letters, an "\&c. \& c." is used for cutting short recitals of standard polite phrases, whether those of Mr Bingley in Pride and Prejudice (344), or those of Mr Elliot in Persuasion (143). It is employed to echo Anne's impatience at observing the Misses Musgroves' naïve and flirtatious questioning of Captein Wentworth (64) in the latter novel. Interestingly, it also demonstrates the intrusive narrator's dismissal of genre expectations, such as describing the obligatory sights of a region (240) in Pride and Prejudice.

If translators abuse such abbreviations, the result is a different style and tone than Austen's. Furthermore, Lalli Knutsen inserts an added "of course" in several places. ${ }^{31}$ Eivind and Elisabeth Hauge clutter up Austen's sentences with modifiers like "a little", "somewhat", or the Norwegian "altså", which sounds rather more helpless than its English equivalents such as "then" or "so". If overused, it tends to be a sign of a teenage girl's superficial idiom, similar to the present-day prevalence of "like" among young Americans and their imitators. However, here it is the narrator's language. Significantly, even the very last word of the Hauges' translation is such an unnecessary appendix to Austen's text: the word "again" is added to "uniting them".32

Some samples of the use of "little" and "somewhat" illustrate the effect: "Elizabeth felt a little unwell";33 "It pleased Elizabeth and gave her a somewhat

28 Austen, Stolthet og fordom, c. 1972, 153.

29 "bl.a.", meaning "blant andre" ("among others"), ibid., 164).

$30 \quad$ "m.v"; "etc.", "f. ex." (Austen, Familien Elliot, 1 January 1872, 29 December 1871).

31 "selvfølgelig" (Austen, Stolthet og fordom, 1947, 69, 71).

32 "igjen" (Austen, Stolthet og fordom, c. 1972, 137, 311). When considering the consequences of the choice of words, the last words of a work are presumably significant. It is hardly a coincidence that the novel ends with the words "uniting them". Several translators keep this effect. Knutsen has "their reconciliation" and Alfsen "unite them" ("deres forsoning", Austen, Stolthet og fordom, 1947, 336; "føre dem sammen", Austen, Stolthet og fordom, 2003, 358). Harbitz, although keeping the meaning of the sentence, turns the word order around and ends with "to Derbyshire", which is a pointless change of the last words from love to geography ("til Derbyshire", Austen, Elizabeth og hennes søstre, 1930, 254.) The 1974 translator keeps the word order, but enhances the romance: "led ... the two of them into each other's arms" ("ført ... de to i hverandres armer", Austen Omvei til lykken, 1974, last part). "Elizabeth følte seg litt uvel" (ibid., 203). This is in itself a misunderstanding of "Elizabeth was not comfortable" (Austen, Pride and Prejudice, 1983, 257). 
triumphant feeling"; ${ }^{4}$ "Then she suddenly became $a$ little anxious"; 35 "She felt a little sad" about disappointing him"; ${ }^{36}$ and "Darcy seemed somewhat irritated". ${ }^{37} \mathrm{He}$ proposed to Elizabeth "in a somewhat agitated tone". ${ }^{38}$ The people of Meryton claim to have always "had a little suspicion towards" Wickham. ${ }^{39}$

That Elizabeth "felt a little sorry for" her father is a weak translation of her "wretched reflection" that her father will be worried about her happiness (375). ${ }^{40}$ When she describes herself to her Aunt as "hurt and a little grumpy", it sounds more ridiculous than "too cross to write" $(382) \cdot{ }^{41}$ Jane takes comfort in the thought that Wickham is "a little fond of" Lydia, instead of the original "a real regard for her" (304). ${ }^{42}$

To this list can be added related modifications like "a sort of", "so", and "relatively". 43 This is not the vocabulary of the master stylist, but rather banal additions. Even the stylistically and linguistically superior 1871 translator resorts to "as mentioned" when making a repetition where Austen does not. ${ }^{44}$ Jane Austen is more economical with words than many of her translators.

\section{Useful and Useless Information}

There are additions that do not feel like an impingement on the text of the novel, although preferably they would have been given in annotations. These may be brief explanations of an outdated phenomenon or obsolete word, or

34 "Det gledet Elizabeth og ga henne en litt triumferende følelse" (Austen, Stolthet og fordom, c. 1972, 201). The original sentence is "Elizabeth could not but be pleased, could not but triumph" (Austen, Pride and Prejudice, 1983, 255).

35 "Da ble hun plutselig litt engstelig" (Austen, Stolthet og fordom, c. 1972, 211). It is a poor exchange for "she began to regret" (Austen, Pride and Prejudice, 1983, 268).

36 "hun følte seg også litt bedrøvet" (Austen, Stolthet og fordom, c. 1972, 153). Austen has: "she was at first sorry" (Austen, Pride and Prejudice, 1983, 189).

"virket noe irritert" (Austen, Stolthet og fordom, c. 1972, 212). Darcy was originally described as having a "heightened complexion" (Austen, Pride and Prejudice, 1983, 269).

38 "i en litt opphisset tone" (Austen, Stolthet og fordom, c. 1972, 153). Austen's version is: "in an agitated manner" (Austen, Pride and Prejudice, 1983, 189).

"hadde hatt litt mistanke til" (Austen, Stolthet og fordom, c. 1972, 231). The original is "had always distrusted" (Austen, Pride and Prejudice, 1983, 295).

$40 \quad$ "syntes litt synd på han" (Austen, Stolthet og fordom, c. 1972, 300).

41 "såret og litt sur" (ibid., 306).

42 "litt glad i henne" (ibid., 239).

43 "en slags"; "såpass"; "forholdsvis" (ibid., 258, 268, 270).

44 "som sagt” (Austen, Familien Elliot, 21 December 1871). 
other useful nuggets of information. Such cases are sometimes referred to as "pragmatic explicitations", since they are there to clarify the different cultural contexts of target and source language. ${ }^{45}$ The 1871 translator of Persuasion, for instance, provides the title of the poem Captain Benwick quotes to Anne in Chapter 12 (it is Byron's “The Corsair"). ${ }^{46}$ In another instance, a proverb that is only alluded to in Austen is supplied in full. ${ }^{47}$

A hundred years later, the pieces of information added by the Hauges to Pride and Prejudice are of more uncertain value. They add "Mrs. Bennet" as an explanation of who Mrs Phillips' sister is, which is hardly necessary at the end of a novel where we have seen both of them. ${ }^{48}$ When Elizabeth signs her letter to her Aunt "Your's, \&c." (383), the Hauges fill in the missing "truly". More inappropriately, they make Mr Bennet sign himself "your dedicated friend" to Mr Collins. ${ }^{49}$

Many of their additions are pointless supplements, for instance that breakfast is "the day after" the evening before; ${ }^{50}$ that people asked questions "one after the other"51 or that Mrs Bennet is at the window "as usual".52

One episode - the dinner party in III, 12 - can serve as example of the accumulated effect of such additions. Rather as if they do not trust Austen to say enough, the translators frequently add explanations. Waiting for Darcy to come in from the dining room "almost made her [Elizabeth] uncivil" (341), we read, but the Hauges add "towards the female guests". ${ }^{33}$ Austen says "the ladies all rose" (342) but the Hauges add "to take their seats at the card tables". 54 "You must not suspect me" Jane says to Elizabeth (343), but the Hauges add "of saying something different than what I mean!".55 This practice of adding little bits goes hand in hand with their previously observed habit of making small cuts.

Likewise, Lady Catherine's appeal to Elizabeth to stay within "the sphere, in which you have been brought up" (356) is extended with "and [is] used to". ${ }^{56}$

45 See Routledge Encyclopedia of Translation Studies, 83.

46 Ibid., 3 January 1872.

$47 \quad$ Ibid., 31 December 1871.

48 Austen, Stolthet og fordom, c. 1972, 307.

49 "hengivne"; "venn" (ibid., 306).

$50 \quad$ "dagen etter" (ibid., 210).

$5^{1} \quad$ "i tur og orden" (ibid., 297). The new phrase seems to replace "when they sat down to table" (Austen, Pride and Prejudice, 1983, 372).

$5^{2}$ "som vanlig" (Austen, Stolthet og fordom, c. 1972, 299).

53 "overfor de kvinnelige gjestene" (ibid., 269).

54 "for å ta plass ved spillebordene" (ibid., 270).

55 “for å si noe annet enn det jeg mener!" (ibid., 271).

$5^{6}$ “og vant til" (ibid., 283). 
When Lady Catherine agrees to call on Elizabeth and Darcy on the final page, an "at last" is added, as if it is something longed for. ${ }^{57}$

\section{Interpretations and Complications}

Some of these additions are interpretive ones, such as Elizabeth talking "so eagerly with" Charlotte when Austen only has "was in conversation with her" (90). ${ }^{58}$ That Georgiana wants to like Elizabeth "if for no other reason, then for her brother's sake"; 59 that Darcy was Wickham's best man; ${ }^{60}$ and Mr Collins calls on the ladies at Rosings "in their loneliness" are examples of translators reading between the lines. ${ }^{61}$ There is often a willingness to perform exegesis as well as translation.

When Darcy defends Elizabeth's tan by putting it down to "travelling in the summer" (271), the Hauges add "and long sojourns out of doors".62 More questionably, they have added "shame" to Miss Darcy's feelings at hearing Wickham mentioned, while in Austen she is "overcome with confusion" (269). ${ }^{63}$

In Wickham's unkind judgement on Darcy's character, that only his pride makes him do good, the addition "not because he really felt like doing it" is rather a let-down (81). ${ }^{64}$ It must be a sign that the translators find Austen's text difficult, but in the mouth of the elegant Mr Wickham, it sounds too flat.

The least felicitous kind of addition consists in complications, where the new version seems awkward, or the meaning becomes muddled. Austen's sentence "he must know my father can give her nothing" (273) is, for example, extended to "He must be aware that father cannot contribute economic support and that Lydia has no money of her own".65 It is difficult to consider this an improvement.

\footnotetext{
57 "endelig" (ibid., 310).

$5^{8} \quad$ "snakket så ivrig med henne" (ibid., 78).

59 "om ikke for annet, så for brorens skyld" (ibid., 206).

6o "var der som forlover" (ibid., 251). Austen only says "was to come there with" (Austen, Pride and Prejudice, 1983, 253).

61 "I deres ensomhet" (Austen, Stolthet og fordom, c. 1972, 170).

62 "og lange opphold ute i naturen" (ibid., 213).

63 "skam og forvirring"(ibid., 212).

64 "ikke fordi han egentlig hadde lyst å gjøre det" (ibid., 72).

65 "Han må være klar over at far ikke kan yte økonomisk støtte og at Lydia ikke har egne penger" (ibid., 215).
} 
Austen is concise and to the point: "Though Lydia had never been a favourite with them, Mr and Mrs Gardiner could not but be deeply affected" (280). The Hauges lengthen and change this to: "Although neither Mr. nor Mrs. Gardiner had ever cared very much for Lydia, they still were very affected by what had happened and were worried about her fate". 66

It is a paradox that the same translators who otherwise abbreviate Austen's text are equally ready to expand and complicate it. Doubly regrettable are the cases when Austen's meaning as well as tone are lost. Elizabeth's desperate outburst when hearing of Lydia's elopement: "But it is all, all too late now" (277) is adjusted to "But it is too late to complain of this now!". ${ }^{67}$ Elizabeth's concern is not that it is too late to complain, but that it is too late to do anything to save Lydia.

The unknown 1974 translator of the Pride and Prejudice serial is more consistent in sticking to the strategy of abbreviation, and dabbles much less in expansion. Still, she does on occasion add a dull summary ("And then she told the whole story..."). ${ }^{68}$

The most recent translator, Merete Alfsen, is far warier about adding to Austen's text than her predecessors. Only when looking very closely do we notice a handful of very minor examples, and none of them probably considered additions by the translator, but rather ways of clarifying the meaning. She makes Elizabeth talk of Darcy's "unease" when the original only has an unspecified "that" (368) ${ }^{69}$ A jokingly penitent expression like "my trespasses" is added to Mr Darcy's confessing to Mr Bingley what he had done (382). ${ }^{70}$ To add "social atmosphere" to "all the comfort and elegance" of Pemberley (384) is a reasonable interpretation, although a verbal addition to Austen's text. ${ }^{71}$ The finds are few and far between in the 2003 translation. Merete Alfsen is, in fact, the only Norwegian Austen translator that seems to feel that Austen's own text suffices, and needs no expansion.

Some translation scholars have claimed that expansion (or explicitation) is a more common strategy than omission (or implicitation), and even that

66 "Skjønt hverken Mr. eller Mrs. Gardiner noen gang hadde vært særlig begeistret for Lydia, så tok de seg meget nær av det som var skjedd og var bekymret for hennes skjebne" (ibid., 220).

67 "Men det er for sent å klage over dette nå!" (ibid., 217).

68 "Og Elizabeth fortalte..."; "så fortalte hun hele historien" (Austen, Omvei til lykken, 1974, last instalment).

69 “din uro" (Austen, Stolthet og fordom, 2003, 339).

70 "min brøde" (ibid., 352).

71 "omgangstonen" (ibid., 354). 
translations are always longer than the originals. ${ }^{72}$ Clearly, this claim can only be made if substantially abbreviated versions are not considered translations, but instead adaptations. For the present purpose, it suffices to note a predilection for both techniques in our Norwegian material, which leads to the suspicion that Jane Austen is liberally expanded as well as shortened in her numerous translations across the world and across time.

72 This is the "explicitation hypothesis" as put forward by Shoshana Blum-Kulka for instance (see Routledge Encyclopedia of Translation Studies, 84). 


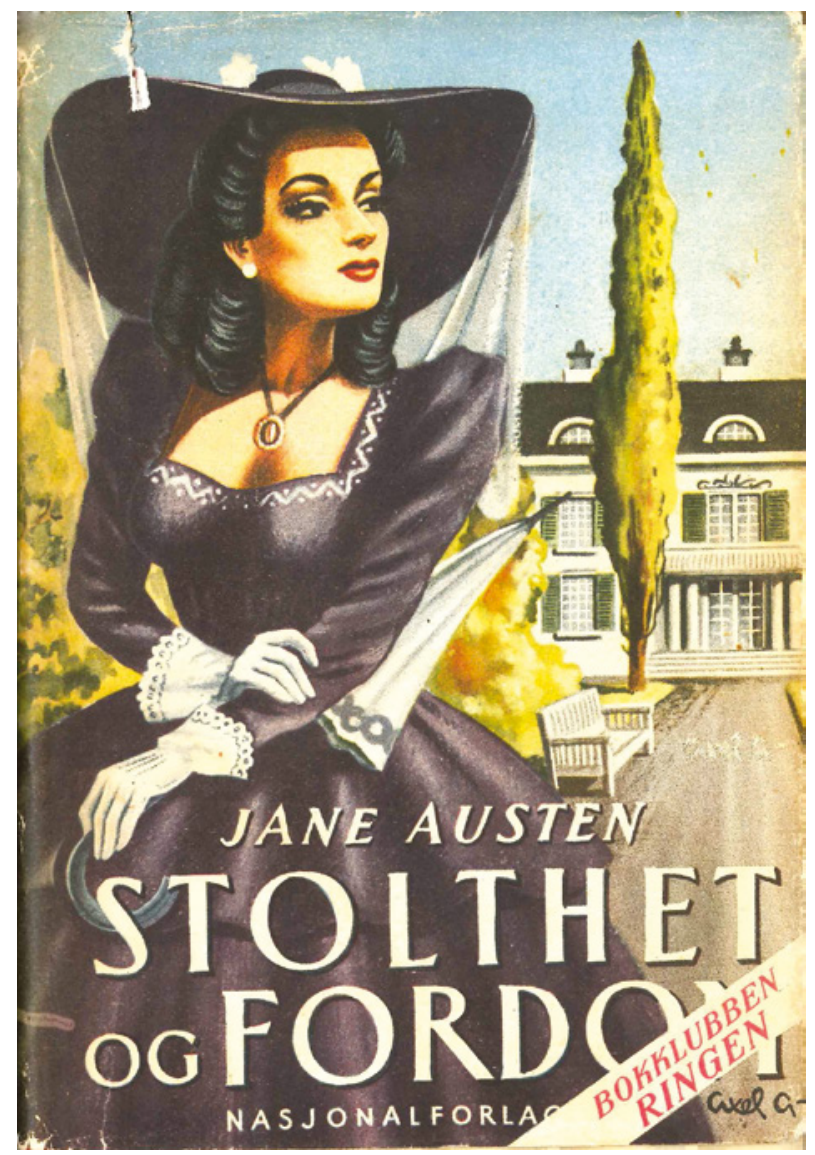

FIGURE 4 Axel Andersen's dustjacket for the 1947 translation of Pride and Prejudice bears witness of the influence of Hollywood productions. 


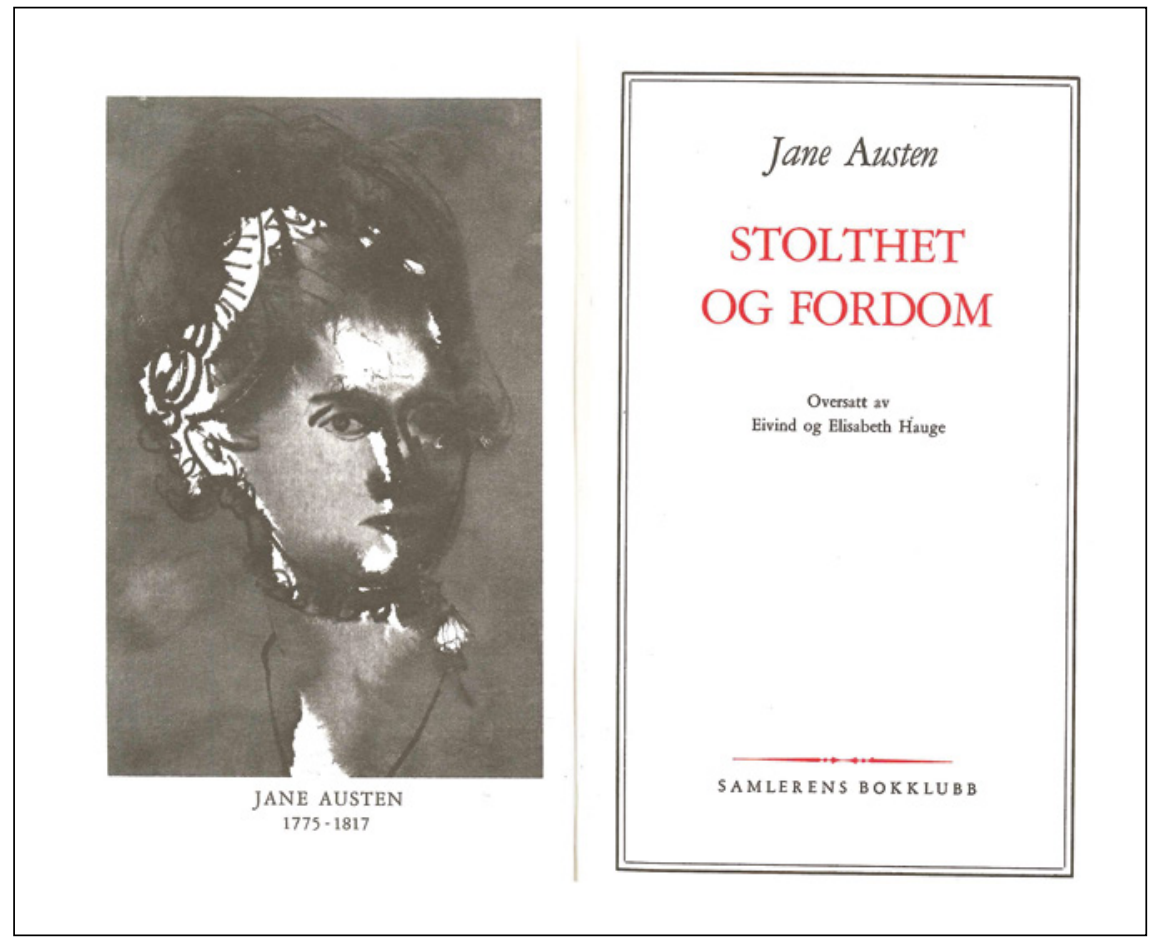

FIGURE 5 The circa 1972 translation of Pride and Prejudice includes illustrations by Sandra Archibald. 